\title{
The Implementation of Scramble Learning Model to Improve Civics Education Learning Achievement of MIM 1 Jombang Students
}

\author{
Firman Firman*
}

\author{
${ }^{1}$ STKIP PGRI Jombang \\ *Corresponding author. Email: namrif63@gmail.com
}

\begin{abstract}
A teacher's success in creating a conducive classroom must be supported by his skills in managing the classroom, learning media, and learning models. Teachers use the learning model to increase learning motivation, students' learning attitudes, critical thinking, social skills, and attain optimal learning achievement. One kind of a new learning model in education is Scramble learning model. This study aims to explain: (1) the learning achievement of MIM 1 Jombang students after the Scramble learning model was implemented in their learning, (2) Civics Education learning achievement of MIM 1 Jombang students before the Scramble learning model was implemented in their learning, (3) the implementation of the Scramble learning model to improve Civics Education learning achievement of MIM 1 Jombang students. This research is quantitative. It, specifically, is population research, where the sample used is 34 students of MIM 1 Jombang. The data are collected using tests, observations, interviews, and documentation and analyzed by using a paired samples t-test with the help of the SPSS program. The data analysis results indicate a significant effect of implementing the Scramble learning model in improving Civics Education learning achievement of MIM 1 Jombang students.
\end{abstract}

Keywords: Scramble Learning Model, Civics Education Learning Achievement

\section{INTRODUCTION}

In Indonesia, education still requires very serious attention because several factors have hindered the development of education. Therefore, to overcome these problems, a teacher is required to have skills in the learning process. Education is the right of all Indonesian citizens as stated in the 1945 Constitution chapter 31 paragraph 1 "Every citizen has the right to education" (the 1945 Constitution: 44). In addition, education has instructional objectives as stated in the Constitution number 20 of 2003 on the national education system. As stated above, the researcher analyses that education must be comprehensive, impartial, democratic, objective, and sustainable.

In order to realize the main goals of national education under the Constitution on the National Education System, a teacher is required to be able to create conducive learning that involves students as a whole so that learning will be more meaningful for students. A teacher's success in creating these conditions is supported by the skills of a teacher in managing the classroom, using learning media, and using learning models. Various learning models are currently developed to optimize educational achievement, which refers to learning motivation, learning attitudes among students, critical thinking, and social skills to achieve more optimal learning outcomes. For this reason, the development of learning models from time to time continues to change. Traditional learning models are now starting to be left and replaced with more modern models.

In general, the learning model is the conceptual framework used as a guide in conducting learning. A learning model is a form of learning presented by the teacher from beginning to end in the classroom. Meanwhile, Joyce defines the learning model as a plan or pattern. This pattern will guide the teachers to plan the learning activities in class or tutorials and determine the learning tools used in the learning process. The learning model consists of a strategy for achieving student competence with approaches, methods, and learning techniques. 
Besides the objectives and goals to be achieved in a learning process, the learning model has five essential elements: syntax, social system, principles of reaction, support system, and instructional and nurturant effect. Syntax refers to the stages of using the model. It describes the sequence of implementation of the model. In comparison, the social system explains the roles and relationships between learners and teachers in a learning situation. It also describes the norms, values, and rules that both students and teachers must obey. The principles of reaction relate to how teachers should perceive, treat, and respond to students.

Meanwhile, the support system is concerned with providing support (i.e. facilities, materials, tools, learning environments) to implement the learning model. And the instructional and nurturant effects refer to the learning outcomes. The learning outcomes could be directly obtained as the result of learning objectives (instructional effect) and/or learning outcomes (nurturant effect)[3].

Currently, various kinds of learning models have been developed. One of them is the scramble learning model. Scramble is learning with media which activities consist of: (1) making questions that follow the competencies to be achieved. (2) making a randomized answer. The teacher's steps present the material under the competencies to be completed. Distribute worksheets according to the example[3]. This Scramble learning model aims to make the students more enthusiastic and actively participate during the lessons to reach satisfying learning achievements. The Scramble Learning Model is an appropriate technique to improve student learning achievement with a simple but interesting method that students will be more motivated, enthusiastic, disciplined, and passionate in participating in learning activities from beginning to end.

The scramble learning model has several advantages as follows: (1) makes it easier to find the answers, (2) encourages students to learn to answer the questions, (3) all students are involved, (4) these activities can encourage students' understanding of the subject matter, (5) train for discipline. On the other hand, it has several weaknesses such as (1) Students lack critical thinking, (2) It is possible to copy other friends' answers, (3) Turn off student creativity, (4) Students just receive raw materials

Some steps that should be carried out to implement the scramble learning model are: preparing the media; (1) Make some answers that have been scrambled letters, (2) Make questions that are in accordance with the competencies to be achieved. steps; (1) The teacher presents the material in accordance with the competencies to be achieved. (2) Distribute worksheets according to the example[3]. From the description above, the researchers analyzed that the learning methods used by teachers also greatly affect the students' learning achievements.

Learning achievement in education is a result of the students' measurement. It includes cognitive, affective, and psychomotor factors. The students' learning achievement is measured after they participate in the learning process by using relevant instruments. One of the instruments which are commonly used to measure students' achievement is a test. A test is a series of questions that need to be answered or responded to to measure the person's ability level to reveal certain aspects of the person being tested. Test results can be used to monitor the education quality development. The test results for this purpose should be good, means that it has the smallest possible measurement error. However, non-test in the teaching and learning process as assessment is an inseparable part, an integral part of learning. The concept of a competency-based curriculum such as KTSP requires the fulfillment of three domains as indicators of success. These three domains are thinking ability, task skills, and behavior. Each student has potential in two domains, namely thinking ability and task skills, but the level from one student to another can be different [4]

Civics Education and personality subject groups are intended to increase students' awareness and insight into their status, rights, and obligations in their social life, nation, and state and improve their quality as human beings. The awareness and insight are including national insight, spirit, and patriotism to defend the country, respect for human rights, national pluralism, environmental conservation, gender equality, democracy, social responsibility, obedience to the law, obedience to pay taxes, also attitude and behavior of anti-corruption, collusion, and nepotism. [1]

After making the observations about the conditions of the school, the researchers found the problem experienced by the students of MIM 1 Jombang. The students have difficulties increasing their learning achievement, especially in Civics Education subjects on the formulation of Pancasila as the Basic State with minimum completeness criteria (KKM) set at 75 . Among 34 students, the students who have achieved learning mastery are $52 \%$ or about 18 students, while the students who have not attained learning mastery are $47 \%$ or 16 students. Watching the conditions during the learning process, the researchers observed that the teacher's activities used conventional models (lectures, questions, answers, assignments). Therefore, it was necessary to do innovative, creative, and fun learning.

\section{RESEARCH METHOD}

\subsection{Research Design}

A method is a procedure or way to find out something that has systematic steps. While the 
methodology is a study in learning the rules contained in the research[7] Therefore, this research design is: Design 2: Pre-test and Post-test Group As for the design/design that the researchers as follows:

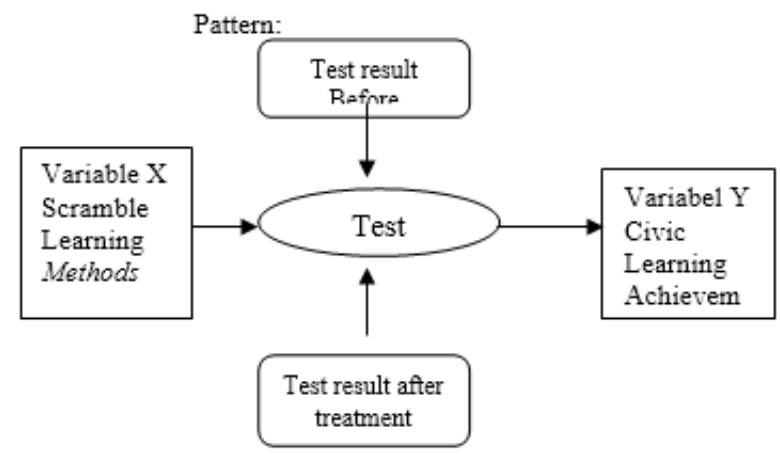

In this cycle, observation was conducted twice, before the experiment and after the experiment. Observations administered before the experiment (01) were called pre-tests, while post-tests were observations conducted after experiments (02).

The difference between $0_{1}$ and 02 , i.e., $0_{1}-0_{2}$, was assumed as the effect of treatment or experimentation [5]

\subsection{Population}

The population is defined as all calculations and measurements' values, quantitatively or qualitatively, rather than certain characteristics of a complete and specific group of objects. In addition, a sample (example) exhibited a portion of the population members sorted by administering a specific technique called a sampling technique [7].

When the amount of the research subject is less than 100 , then take them all as the population research was highly advised [5]. On the other hand, when the number of subjects is large, it can be taken between $10-15 \%$ or $20-25 \%$

Based on the students total number who sit on class VI MIM 1 Jombang is 34 learners, less than 100, this study was classified as population research.

\subsection{Data Collection Procedure}

To obtain complete, precise, and correct data, the researcher carried on some crucial stages, as the following;

1. Preparation stage

a. Determining the type of data,

b. Sizing up the data source,

c. Determining the data analysis processes.

2. Implementation stage

In this stage, the researcher observed and gathered all the data by conducting observations and collecting the crucial documents dealing with the research to the school.

3. Data processing stage
After the data were collected, the researcher processed them by implementing the appropriate data analysis formula.

\subsection{Data Collection}

The data in this research were collected through observation, tests, interviews, and documents. The techniques are explained in detail as follows:

\section{Observation Method}

Systematic observation is an observation in which the observed factors have been listed systematically and arranged according to their category[6]. Researchers made observations during the learning process. This researcher observes learners' activities in learning together in the context of small groups, explores the knowledge and understanding of learners about the subject matter, and gets to know the attitudes and behavior of learners during learning activities.

\section{Interview}

The interview exhibited some frequent and relevant unilateral questions to get answers from respondents. It is said to be one-sided because, in this interview, respondents were not given the opportunity at all to ask questions. The evaluation subject only asks questions[6]

In this case, researchers use the open-ended interview method, where the respondents have the freedom to express their opinions without being limited by the specific restriction that the evaluation subjects have formulated. Researchers used this method to collect learners' backgrounds, social life, motivation, interests, and environmental conditions. In addition, this method was used by researchers to find out the learners' respond during the learning process before and after the scramble learning model was implemented.

\section{Test Method}

The test method is conducted by administering questions or exercises and other tools to organize skills, intelligence knowledge, abilities, or talents possessed by individuals or groups[5]. The researchers applied this method to obtain data on the students' learning achievements in class VI MIM 1 Jombang.

\section{Documentation Methods}

The data collection technique with documentation upholds where the data is obtained through relevant documents. The documentation method implemented by the researcher aims to retrieve data dealt with the number of learners, the student's identification number, and the students' names. Besides, it also aims to get other crucial general information regarding the school itself, such as the vision of the school's mission, the names of teachers, and so on. Those data were obtained from The school Administration bureau. In addition, the researcher filed the learning process in the form of photo documentation. 


\subsection{Test Item Validity}

This analysis uses the following analysis:

\subsubsection{Validity}

Correlation formula with product moment with rough numbers

$\operatorname{rxy}=\frac{N \Sigma X Y-\left(\sum X\right)\left(\sum \mathrm{Y}\right)}{\sqrt{\left(N \Sigma X^{2}-(\Sigma X)^{2}\right)\left(N \Sigma Y^{2}-(\Sigma Y)^{2}\right)}}$

Where:

$r_{x y}=$ Correlation coefficient between variables $X$ and $\mathrm{Y}$, two correlated variables.

$\mathrm{N}=$ Number of test participants

$\mathrm{X}=$ Test score on the item of the question it seeks validity

$\mathrm{Y}=$ Standardized test score

Table 1. Interpretation of the correlation coefficient

\begin{tabular}{ll}
\hline Correlation coefficient & Interpretation \\
\hline Between 0.800 to 1.00 & Very high \\
Between 0.600 to 0.800 & High \\
Between 0.400 to 0.600 & Moderate \\
Between 0.200 to 0.400 & Low \\
Between 0.00 to 0.200 & Very low
\end{tabular}

(Arikunto, 2003: 75)

\subsubsection{Reliability}

To find reliability, the researcher implemented the formula Hyot, as the following:

$$
\begin{aligned}
& \mathrm{r}_{11}=1-\underline{\mathrm{Vs}} \\
& \mathrm{Vr}
\end{aligned}
$$

[6]:

$$
\begin{aligned}
& \mathrm{r}_{11}=\text { Reliability of all problems } \\
& \mathrm{Vs}=\text { Respondent variance } \\
& \mathrm{Vr}=\text { Residual variance }
\end{aligned}
$$

To find the reliability of a problem is done with the following steps:

Step 1. Finding out the number of respondents square with the formula:

$$
J \mathrm{k}(\mathrm{r})=\sum \underline{\mathrm{X}}_{\mathrm{t}}^{2}-\underline{\mathrm{X}}_{\mathrm{t})^{2}} \mathrm{kx} \mathrm{N}^{2}
$$

Note:

$$
\begin{aligned}
& \mathrm{Jk}(\mathrm{r})=\text { number of respondents squared } \\
& \mathrm{X}_{\mathrm{t}}=\text { total score of each respondent } \\
& \mathrm{k}=\text { number of items } \\
& \mathrm{N}=\text { number of respondents or subjects }
\end{aligned}
$$

Step 2. Searches the sum of the squares of the item with the formula:

$$
\mathrm{Jk}(\mathrm{i})=\sum_{\mathrm{B}}^{2}-\frac{\left(\sum \mathrm{X}^{\mathrm{t}}\right)^{2}}{\mathrm{kx} \mathrm{N}}
$$

Note:

$\mathrm{Jk}(\mathrm{i})=$ number of squares of items

$\sum \mathrm{B}^{2}=$ correct number of squares of the entire item

$\left(\sum X_{t}\right)=$ the square of the total score
Step 3. Find the sum of total squares with formula

$$
J \mathrm{k}(\mathrm{t})=\frac{\left(\sum \mathrm{B}\right)-\left(\sum \mathrm{S}\right)}{\left(\sum \mathrm{B}\right)+\left(\sum \mathrm{S}\right)}
$$

Note:

$\mathrm{Jk}_{\mathrm{t}}=$ total squared amount

$\sum \mathrm{B}=$ number of correct answers to all items

$\sum \mathrm{S}=$ number of incorrect answers of the entire item

Step 4. Find the sum of the squares of the remainder:

$$
\mathrm{Jk}(\mathrm{s})=\mathrm{Jk}(\mathrm{t})-\mathrm{Jk}(\mathrm{r})-\mathrm{Jk}(\mathrm{i})
$$

table F

Step 5. Look for the respondent's variance with

In finding this variance, we need $\mathrm{db}$ (degrees of freedom) from each source of variance, and then this $\mathrm{db}$ is used as the denominator of each sum of squares to obtain the variance.

d.b $=$ the number of $\mathrm{N}$ each source of variance minus 1 so, variance $=\frac{\text { sum of squares }}{\mathrm{db}}$

Step 6. Plugging into the formula r11

$$
r 11=1-\frac{v s}{\nu r}
$$

The instrument's reliability shows the extent to which a measurement can give the same results if repeated measurements are made on the same research subject. A data can be said to be reliable if the value of Cronbach's Alpha / Reliability Coefficients (Alpha) is greater than $0.60 "$.

\subsection{Data Analysis}

Data Analysis Techniques used by the researcher intend to test the hypotheses. Restating the design, this research implements quantitative research methods with experimental research types, "The Implementation of Scramble Learning Model to Improve Civics Learning Achievement of MIM 1 Jombang Students". The data obtained from observation, tests, and documentation were analyzed using the statistical formula t-test test (different test). Furthermore, the researchers used the ttest test formula to determine whether or not there is an influence and the magnitude of the influence of the application of the scramble learning model in improving four grade students' Civics learning achievement at MIM 1 Jombang.

In processing the data, researchers used an alternative program SPSS 16.0 for Windows[9]. The steps for conducting data analysis are as follows:

1. determine the null hypothesis test (Ho) and alternative hypothesis (Ha);

2. look for the probability value/sig (p) with a significant level $(\alpha) 5 \%$;

3 . determine the acceptance or rejection of Ho and Ha with the following test criteria:

a. if $\mathrm{p}$ value $>$ or $\mathrm{t}$ count $<\mathrm{t}$ table then Ho is accepted, and $\mathrm{Ha}$ is rejected

b. if the value of $\mathrm{p}<$ or the value of $\mathrm{t}$ count $>\mathrm{t}$ table, then Ho is rejected, and $\mathrm{Ha}$ is accepted 4. conclusion. 


\section{RESULT AND DISCUSSION}

This research was conducted at MIM Jombang. In this study, one class was used as the research sample, namely class VI, which consisted of 34 students. The sampling technique takes the whole sample from the population, which means that each member of the population becomes the overall research sample because the subject is less than 100 .

In collecting data on student learning achievement, it was obtained from the attitude values of students during the learning process using attitude assessments that led to the affective domain, and from students' test scores after the learning process by using written assessments that led to the cognitive domain.

\subsection{Result}

1. Students' Civics Learning Achievement after the Implementation of the Scramble Learning Model.

The results of students' achievement in the Civics learning process after applying the scramble learning model can be seen in Table 2 below [9].

Table 2. Learning Achievement After applying the Learning Model Scramble

\begin{tabular}{|c|c|c|}
\hline No. & Students' name & Score \\
\hline 1 & $\mathrm{~F}$ & 73,3 \\
\hline 2 & $\mathrm{AF}$ & 86,7 \\
\hline 3 & BS & 80 \\
\hline 4 & $\mathrm{JA}$ & 80 \\
\hline 5 & MM & 86,7 \\
\hline 6 & MAP & 80 \\
\hline 7 & M & 80 \\
\hline 8 & W & 80 \\
\hline 9 & YTF & 80 \\
\hline 10 & DA & 100 \\
\hline 11 & GA & 93,3 \\
\hline 12 & MA & 86,7 \\
\hline 13 & NS & 86,7 \\
\hline 14 & RA & 73,3 \\
\hline 15 & SW & 80 \\
\hline 16 & TAD & 86,7 \\
\hline 17 & YV & 86,7 \\
\hline 18 & MR & 80 \\
\hline 19 & SP & 80 \\
\hline 20 & AA & 86,7 \\
\hline 21 & DSN & 100 \\
\hline 22 & RO & 80 \\
\hline 23 & MFR & 80 \\
\hline 24 & FI & 80 \\
\hline 25 & RR & 80 \\
\hline 26 & MS & 73,3 \\
\hline 27 & FT & 86,7 \\
\hline 28 & EI & 80 \\
\hline 29 & DA & 80 \\
\hline 30 & $\mathrm{AF}$ & 80 \\
\hline
\end{tabular}

\begin{tabular}{rcc}
\hline No. & Students' name & Score \\
\hline 31 & LAS & 80 \\
32 & MRR & 80 \\
33 & M FE & 80 \\
34 & DY & 80 \\
\hline
\end{tabular}

2. Students' Civics Learning Achievement before the Implementation of the Scramble Learning Model. Students' achievement results in the Civics learning before the Scramble learning model are presented in Table 3. below.

Table 3. Learning Achievement Before the Scramble Learning Model is applied

\begin{tabular}{|c|c|c|}
\hline No. & Students' name & Score \\
\hline 1 & $\mathrm{~F}$ & 63,3 \\
\hline 2 & $\mathrm{AF}$ & 73,3 \\
\hline 3 & BS & 66,7 \\
\hline 4 & JA & 73,3 \\
\hline 5 & MM & 73,3 \\
\hline 6 & MAP & 80 \\
\hline 7 & M & 73,3 \\
\hline 8 & $\mathrm{~W}$ & 73,3 \\
\hline 9 & YTF & 53,3 \\
\hline 10 & DA & 86,7 \\
\hline 11 & GA & 86,7 \\
\hline 12 & MA & 73,3 \\
\hline 13 & NS & 73,3 \\
\hline 14 & RA & 66,7 \\
\hline 15 & SW & 73,3 \\
\hline 16 & TAD & 73,3 \\
\hline 17 & YV & 73,3 \\
\hline 18 & MR & 80 \\
\hline 19 & SP & 80 \\
\hline 20 & AA & 80 \\
\hline 21 & DSN & 93,3 \\
\hline 22 & RO & 73,3 \\
\hline 23 & MFR & 73,3 \\
\hline 24 & FI & 73,3 \\
\hline 25 & RR & 80 \\
\hline 26 & MS & 53,3 \\
\hline 27 & FT & 80 \\
\hline 28 & EI & 73,3 \\
\hline 29 & DA & 66,7 \\
\hline 30 & $\mathrm{AF}$ & 73,3 \\
\hline 31 & LAS & 73,3 \\
\hline 32 & MRR & 80 \\
\hline 33 & M FE & 73,3 \\
\hline 34 & DY & 66,7 \\
\hline
\end{tabular}

Source: data processed from research results, 2012.

After the research data are obtained and presented in the table above, data analysis is next. The data analysis aims to test the hypothesis. The hypothesis is tested and analyzed using the t-test technique (differential test) of two paired samples. Before determining the conclusions from the results of the analysis, the hypotheses are established.

Ho $=$ there is no significant effect of implementing the Scramble Learning Model on Civics 
learning achievement of the six-grade students of MIM 1 Jombang.

$\mathrm{Ha}=$ there is a significant effect of implementing the Scramble Learning Model on Civics learning achievement of the six-grade students of MIM 1 Jombang.

The hypothesis testing criteria are:

a. if the sig. value $(\mathrm{p})>\alpha$ value .05 or the $\mathrm{t}$-value < t-table means that Ho (null hypothesis) is accepted, and the Ha (alternative hypothesis) is rejected. b. if the sig. value (p) $\langle\alpha$ value .05 or the t-value $>$ t-table means that the Ho (null hypothesis) is rejected, and the Ha (alternative hypothesis) is accepted.

The output or results of calculations or data processing using SPSS 16.0 for Windows with the complete paired sample T-test method are presented in Table 4.

Table 4. Paired Samples Statistics

\begin{tabular}{llrrrc}
\hline & Mean & $N$ & Std. Deviation & Std. Error Mean \\
\hline Pair 1 & The result after & 82,5529 & 34 & 8,05057 & 1.38066 \\
& The result before & 73,8088 & 34 & 6,15232 & 1.05511 \\
\hline
\end{tabular}

Table 4. Paired samples statistics show a summary of the mean and standard deviation of the two[8] comparisons. The average student score after applying the Scramble learning model was 82.5529 . On the other hand, before using the Scramble learning model, the mean score of the students was 73.8088 .

Table 5. Paired Samples Test

\begin{tabular}{|c|c|c|c|c|c|c|c|c|}
\hline & \multicolumn{5}{|c|}{ Paired Differences } & \multirow[b]{3}{*}{$\mathrm{t}$} & \multirow[b]{3}{*}{$\mathrm{f}$} & \multirow{3}{*}{$\begin{array}{l}\text { Sig. }(2 \\
\text { tailed })\end{array}$} \\
\hline & \multirow[b]{2}{*}{ Mean } & \multirow{2}{*}{$\begin{array}{c}\text { Std. } \\
\text { Deviation }\end{array}$} & \multirow{2}{*}{$\begin{array}{c}\text { Std. } \\
\text { Error } \\
\text { Mean }\end{array}$} & \multicolumn{2}{|c|}{$\begin{array}{c}95 \% \text { Confidence Interval } \\
\text { of the Difference }\end{array}$} & & & \\
\hline & & & & Lower & Upper & & & \\
\hline $\begin{array}{l}\text { Before-After } \\
\text { Results }\end{array}$ & 8,74412 & 5,80951 & 9,9632 & 10,77115 & 6,71708 & 8,776 & 3 & .000 \\
\hline
\end{tabular}

Table 5 above shows the results of Paired Sample Test. It can be seen that the mean is 8.74412 , and the standard deviation is 5.80951. Meanwhile, the t-value is 8.776. However, the Sig (2-tailed) value is $0.00<0.05$, Ha can be inferred to be accepted, and it is worthwhile to apply Scramble learning model to improve the performance of Civics Learning Achievement for grade VI MIM Jombang students.

\subsection{Interpretation}

After implementing the Scramble Learning Model, the highest score for student learning achievement is 100 , and the lowest score is 73.3. Students had the highest learning score of 93.3 and the lowest score of 53.3 before implementing the Scramble Learning Model. The statistical analysis results using SPSS 16.0 for Windows program application get the average value of learning success after applying the Scramble Learning Model with the combined T-Test method and 73.8088 of the Scramble Learning Model $=73.81$ Average learning success before the application. So the average difference between the two is $8.74412=8.74$. Meanwhile, the t-value is $8.776=8.78$. Furthermore, the $\mathrm{t}$-value is $8.776=8.78$. If this value is discussed in the $\mathrm{t}$-table list with a significant level $(\alpha)$ of $5 \%$ and $\mathrm{df}=$ $\mathrm{N}-1=33$, the t-table is 2.042 . So, $\mathrm{t}$-value $(8.78)>\mathrm{t}$ - table (2.042). Furthermore, from the analysis and statistical results using SPSS 16.0 for Windows program application, a probability value of 0.00 was also obtained. As the probability value $<\alpha$ value $(0.00<$ $0.05)$ and t-value $>$ t-table $(8.78>2.042)$, the Ho is rejected, and the Ha is accepted.

\subsection{Discussion}

From the above statistical analysis results, the Ho is rejected, while the $\mathrm{Ha}$ is accepted. Thus, it can be concluded that there is a significant effect of implementing the Scramble Learning Model on Civics learning achievement of the six-grade students of MIM 1 Jombang. The above result proves that efforts to improve the social science performance of sixth-grade students of MIM 1 Jombang can be achieved through cooperative learning models, one of which is applying the Scramble learning model since the model can improve students' outcomes. It is proven when the use of the Scramble learning model for civil law subjects by sixth-graders shows that it can stimulate learning activity, creativity, critical thinking, motivation, discipline, and social skill for students in small groups. Additionally, it has improved academic performance as students become more active in the learning process and 
become counselors for students from low-income families.

Applying the Scramble Learning model has been shown to increase individual responsibility in group discussions and the overall participation of all students. In essence, the Scramble Learning Model is a kind of group discussion that requires students to be creative, cooperative, and think ahead as they turn words into answers [10].

The situation was much different before the Scramble learning model was applied since, during the learning process, students tended to be passive as listeners and receivers of teacher learning. A few of them only dominate the activeness of students. Students who are active in the learning process tend to be more active in asking questions, arguing, and digging up information from teachers and other learning resources to achieve higher learning achievement. Conversely, less active students tend to be passive in the learning process as they only accept the knowledge that comes to them; consequently, they have lower learning achievement.

\section{CONCLUSION}

After conducting research, data description, data analysis, interpretation, and discussion, the final step is giving conclusions. Based on the result and discussion, the researcher conclusions are as follows:

The implementation of the scramble learning model has a significant effect on the six-grade students' Civics education learning achievement of MIM 1 Jombang. It is evidenced by the results of statistical data analysis that the alternative hypothesis (Ha) is accepted with certain criteria.

The mean score of students' learning outcomes after applying the Scramble learning model was 82.55. On the other hand, the mean score of students' learning outcomes was 73.81 before the scramble learning model was implemented. The difference between the two means is 8.74. It shows that the learning process by applying the Scramble learning model has a positive effect on improving the Civics learning achievement of students of grade VI MIM Jombang.

The objective of the Scramble learning model is to create a learning environment that is effective and efficient, fun, meaningful, and more active for the students, and also subject-oriented.

\section{SUGGESTION}

The researcher may suggest the following suggestions:

The teacher should create a competitive learning environment supported by good classroom management skills and abilities to choose and apply the Scramble learning model to make the learning process meaningful for students.

In teaching the Scramble model, the teacher should motivate the students so that they participate enthusiastically in the learning activity. In addition, the teachers are supposed to monitor the discussion and conduct a series of evaluations. Thus achieving learning achievement can be maximized.

Qualification of teachers through training, seminars, and workshops related to the world of education should be a priority to continuously improve their professionalism since successful education depends on the teacher as the driving force behind the growth of the next generation.

\section{ACKNOWLEDGMENTS}

Thanks to all those who helped the research, especially MIM 1 Jombang.

\section{REFERENCES}

[1] SISDIKNAS, SNP. 2009. Surabaya: Wacana Intelektual Himpunan Peraturan Perundangan Bidang Pendidikan, (Peraturan Menteri Pendidikan Nasional Nomor 22 tahun 2006 Tentang standar Isi Untuk Satuan Pendidikan Dasar dan Menengah). Jombang: 2006.

[2] Isjono. 2009. Pembelajaran Kooperatif Meningkatkan Kecerdasan Komunikas Antar Peserta Didik. Yogyakarta: Pustaka Pelajar.

[3] Lindayani, Dyah Amiyah dan Murtadlo, M Ali. 2011. Manajemen Pembelajaran Inovatif. Surabaya: Arta Sarana Media.

[4] Rasyid, Harun dan Mansur. 2007. Penilaian Hasil Belajar. Bandung: CV. Wacana Prima.

[5] Arikunto, Suharsimi. 2006. Prosedur Penelitian Suatu Pendekatan Praktek. Jakarta: Rineka Cipta.

[6] Arikunto, Suharsimi. 2003. Dasar-Dasar Evaluasi Pendidikan. Jakarta: Bumi Aksara.

[7] Usman, Husaini dan Setiady Akbar, Purnomo. 2008. Metodologi Penelitian

[8] Sudrajad, Akhmad. 2009. Tujuan Pembelajaran Sebagai Komponen Penting Dalam Pembelajaran. ( http://akhmadsudrajad.wordpress.com, diakses 08 Oktober 2012 ).

[9] Sugiyono. 2007. Statistika Untuk Penelitian. Cetakan Keduabelas. Bandung : CV. Alfabeta.

[10] Suprijono, Agus. 2009. Cooperative Learning ( Teori dan Aplikasi PAIKEM ). Antar Peserta Didik. Yogyakarta : Pustaka Pelajar. 